\title{
Stress and stressors in bus drivers
}

\author{
Stresse e stressores em motoristas de autocarros \\ Estrés y estresores en conductores de autobuses
}

Sílvia Elizabeth Gomes de Medeiros*; Jael Maria de Aquino**; Iracema da Silva Frazão***;

Estela Maria Leite Meirelles Monteiro****; Maria Sandra Andrade ${ }^{* * * * *}$; Marlene Gomes Terra*****;

Betânia da Mata Ribeiro Gomes*******

\section{Abstract}

Background: Occupational stress is one of the main pathological disorders triggered by inadequate processes at work.

Objectives: To investigate stress and stressors in bus drivers.

Methodology: A descriptive, exploratory study with a quantitative approach was conducted with 321 bus drivers, using Lipp's Inventory of Stress Symptoms for Adults. The chi-squared test, the Fisher's exact test, and the Likelihood-ratio test $(\mathrm{CI}=95 \%)$ were applied.

Results: In this sample, $75.6 \%$ of the stressed bus drivers are in the resistance phase and $18.6 \%$ are in the exhaustion phase. Stress and its phases were correlated with length of service $(p=0.016)$, rest during working hours $(p<0.001)$, sleep quality $(p=0.001)$, and health self-assessment $(p<0.001)$.

Conclusion: Stress is associated with working time, excessive daily workload, lack of time to rest, and poor sleep quality.

Keywords: burnout, professional; mental health; occupational health

\section{Resumo}

Enquadramento: $\mathrm{O}$ stresse ocupacional é uma das principais desordens patológicas desencadeadas por processos inadequados no trabalho.

Objetivos: Investigar o stresse e stressores em motoristas de autocarros.

Metodologia: Estudo descritivo, exploratório de abordagem quantitativa, desenvolvido com 321 motoristas, utilizando o Inventário de Sintomas de Estresse de Lipp, sendo analisado através dos testes de qui-quadrado, fisher e a razão de verossimilhança (IC = 95\%).

Resultados: Dos stressados, 75,6\% estão na fase de resistência e 18,6\% na fase de exaustão. Houve associação do stresse e das suas fases com o tempo de trabalho na empresa $(p=0,016)$, tempo de descanso durante o horário de trabalho $(p<0,001)$, qualidade do sono $(p=$ $0,001)$ e autoavaliação da saúde $(p<0,001)$.

Conclusáo: $\mathrm{O}$ stresse está relacionado com o tempo de serviço, excessiva carga horária diária, inexistência de horário para o descanso e a péssima qualidade de sono.

Palavras-chave: esgotamento profissional; saúde mental; saúde do trabalhador

\footnotetext{
*MSc., RN, University of Pernambuco, Recife - PE, 50100-010, Brazil [silviaelizabeth89@hotmail.com]. Contribution to the article: literature search, participation in experimentation, data collection, statistical treatment and evaluation, data analysis and discussion, article writing Address for correspondence: Rua Francisco de Paula Machado, Edificio Manoel Aleixo, $n^{\circ} 14$ apt 302, 50100-130, Brazi

* Ph.D., RN, Post-Doctoral Professor, University of Pernambuco, Recife - PE, 50100-010, Brazil [jaelquino@ig.com.br]. Contribution to the article: literature search, participation in expericollection, statistical treatment and evaluation, data analysis and discussion, article writing.

Ph.D., RN, PhD Professor, University of Pernambuco, Recife - PE, 50100-010, Brazil [isfrazao@gmail.com]. Contribution to the article: data analysis and discussion, article writing Ph.D., RN Post-Doctoral Professor, University of Pernambuco, Recife- PE, 50100-010, Brazil estelapf2003@yahoo.com.br].Contribution to the article: data analysis and discussion, article writing.

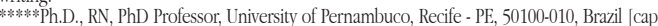
sandra@uol.com.br]. Contribution to the article: data analysis and discussion, article writing.
$* * * * * * * *$ Ph.D., RN, Post-Doctoral Professor, Federal University of Santa Catarina, Florianopoli .SC, 88040-900, Brazil [martesm@hotmail.com.br]. Contribution to the article: data analysis

and discussion, article writing.
$* * * * * * *$ Ph.D., RN, University of Pernambuco, Recife - PE, 50100-010, Brazil lbetania.mata@ upr.br]. Contribution to the article: data analysis and discussion, article writing.
}

\section{Resumen}

Marco contextual: El estrés ocupacional es uno de los principales trastornos patológicos desencadenados por procesos inadecuados en el trabajo.

Objetivos: Investigar el estrés y los estresores en conductores de autobuses.

Metodología: Estudio descriptivo, exploratorio, de enfoque cuantitativo, desarrollado con 321 conductores y en el que se utilizó el Inventario de Síntomas de Estrés de Lipp, el cual se analizó a través de las pruebas de ji cuadrado, Fisher y la razón de verosimilitud (IC $=95 \%$ ). Resultados: De las personas estresadas, el 75,6\% está en la fase de resistencia y el 18,6\% en la de agotamiento. Hubo una asociación del estrés y sus fases con el tiempo de trabajo en la empresa $(p=0,016)$, el tiempo de descanso durante el horario de trabajo $(p<0,001)$, la calidad del sueño $(p=0,001)$ y la autoevaluación de la salud $(p<0,001)$.

Conclusión: El estrés está relacionado con el tiempo de servicio, la carga horaria diaria excesiva, la inexistencia de un horario para descansar y la pésima calidad del sueño.

Palabras clave: agotamiento profesional; salud mental; salud laboral 


\section{Introduction}

Public bus drivers are a professional category of major social importance because they are mediators of mobilization. Thus, studies on the physical and psychological conditions of this professional category may be considered relevant for the assessment of the urban well-being.

Driving is a highly stressful task which is affected by environmental, social, and interpersonal interaction factors. Since they work in a public environment, bus drivers are exposed to adverse traffic conditions, climate changes, and poor road conditions. In addition to these factors, they are also exposed to irregular working hours, low wages, job insecurity, noise and vibration, business demands, damage to equipment, excessive number of stops, schedule-related pressure, among others (Prange, 2011).

Drivers' social role is also reflected in the responsibility for passengers and pedestrians' lives and other vehicles. This commitment makes them somehow insecure in their professional activity, resulting in beneficial actions, such as providing more protection and attention to passersby, but also in actions that lead to fear and conflicts and may therefore trigger illness processes. For these reasons, employers should not consider bus drivers only from the perspective of fulfilling requirements or economic interests, but as unique human beings who are part of the work organization (Baltazar, Maia, Figueiredo, Correia, \& Holanda, 2008).

It should be noted that the stressors to which these professionals are exposed may contribute not only to inadequate traffic attitudes but also to the manifestation of occupational diseases such as stress, fatigue, anxiety, depression, circulatory and vascular diseases, musculoskeletal disorders, noise-induced hearing loss, and reduced self-esteem (Alquimim, Barral, Gomes, \& Rezende, 2012; Guterres, Duarte, Siqueira, \& Silva, 2011).

Interventions aimed at the health and working conditions of this population group are of utmost importance, since public transport is carried out by individuals with biopsychosocial-cultural aspects that deserve special attention; after all, they are not a mechanical gear.

As it is a dynamic process, stress can be worsened if no strategies are implemented to tackle the problem. In turn, the nurse does not seem to be integrated into these professionals' health-related activities. In this context, nursing should emerge as a profession committed to these individuals' physical and mental well-being with a view to health promotion, protection, recovery, and rehabilitation in various care settings. As an integral part of the multidisciplinary team, nurses can be an important facilitator of interventions and monitoring, due to their sensitivity to stress-related physical and mental burnout in bus drivers and to their specific training of integral care delivery to promote health. From this perspective, the aim of this study is to investigate stress and stressors in bus drivers, emphasizing the stress variable as a trigger of physical and psychological disorders.

\section{Background}

Stress is one of the major psychological disorders triggered by inadequate work processes. It was originally defined as a nonspecific reaction of the body to any demand, which may cause physiological changes in case of situations that trigger strong positive or negative emotions (Selye, 1959).

Stress was primarily divided into three stages: alarm, resistance, and exhaustion. The first stage is characterized as positive because of the production of adrenaline, making the individual more alert, creative, productive, motivated, and prepared for action. The second stages requires coping strategies and ensures homeostasis. Once the stressor is removed, the homeostatic balance is established and the physiological process of stress ends. The third stage occurs when stressful factors prevail, leading to processes of illness, depression, and loss of concentration (Lipp, 2004).

Another stage of stress was added to this triad between the resistance and exhaustion 
stages: the near-exhaustion stage (Goulart Júnior \& Lipp, 2008). In this stage, when stress levels rise beyond physiological limits, there is a decrease in physical and emotional strength, and it is necessary to increase efforts to improve the performance of activity of daily activities.

The exhaustion stage is characterized by the failure of homeostasis, which causes a series of conditions such as: high blood pressure, depression, sexual disorders, skin disorders, stroke, and sudden death (Lipp, 2014).

\section{Hypothesis}

The adverse factors to which bus drivers are exposed to on a daily basis lead to the occurrence of stress, as well as to physical and psychological disorders.

\section{Methodology}

A descriptive study with a quantitative approach was conducted in the integrated passenger terminals (IPTs) of the city of Recife, Pernambuco, Brazil. IPTs are intended for bus and passenger circulation, and work as strategic points in the transportation of pedestrians. Buses leave from the IPTs of reference, take passengers to a desired destination, and return to the same point of departure, in several cycles per day.

The study was initially presented to the public relations office of the transportation company Grande Recife Consórcio de Transporte. Then, the letter of consent was sent to the company's board of director for consideration. Once authorized by means of a formal declaration in writing and approved by the ethics and research committee, this project was presented to the supervisor of each IPT. Supervisors were responsible for making individual appointments to explain the research aims and start the data collection process.

Although the study population was composed of 1254 bus drivers, the study only included 321 drivers proportionately distributed throughout all ITPs. In a pilot study, Lipp's Inventory of Stress Symptoms for Adults validated by Lipp and Guevara (1994) was applied to 86 bus drivers. The most prevalent stage of stress (exhaustion) was used to calculate a stratified sample. The present study included bus drivers who were professionally active during the data collection period. Due to the lack of an adequate place for drivers to rest, some places were improvised such as sidewalks, benches, and inside vehicles parked in the station.

Data were collected using a questionnaire designed by the authors on sociodemographic data and daily lifestyles. Stress was analyzed using the Lipp's Inventory of Stress Symptoms for Adults by Lipp and Guevara (1994). This inventory consists of 37 somatic symptoms and 19 psychological symptoms, of which some are repeated and only vary in intensity. These items are divided into three research moments. The first moment assesses the stage of alarm and includes 12 physical symptoms and three psychological symptoms experienced in the past 24 hours. The second moment comprises 10 physical symptoms and five psychological moments experienced in the past week. The stage of near-exhaustion is identified based on a higher frequency of symptoms experienced in the past week. The third and final moment assesses the exhaustion phase through 12 physical symptoms and 11 psychological symptoms experienced in the past month.

The positive diagnosis and stratification of stress are obtained by summing the scores for the symptoms in each table of the inventory. When the number of symptoms exceeds the predetermined limit in each specific stage, stress and its stage is diagnosed $(\mathrm{T} 1>6$ symptoms, indicates the alarm stage; T2 > 3 symptoms, indicates the resistance stage, or T2 $>9$ symptoms, indicates the near-exhaustion stage; and T3 > 8 symptoms, indicates the exhaustion stage; Lipp, 2000).

Data were analyzed through descriptive and inferential statistics. The margin of error used in the decisions of the statistical tests was $5 \%$ and the intervals were obtained 
with a $95 \%$ confidence interval.

The study complies with the ethical principles of research involving human beings, and it was approved by the Research Ethics Committee of the University of Pernambuco, under protocol number 551.421 and registration of the Certificate of Presentation for Ethical Consideration (CAAE): 23683613.6.0000.5192.

\section{Results}

Age ranged between 24 and 69 years, with a mean age of 40.7 years, a standard deviation of 9.5 years, and a median of 40.0 years. Among the participants, $97.2 \%$ were men and $67.6 \%$ were married or in a stable relationship.

With regard to everyday habits, $34 \%$ of the participants had no time for leisure and $76.6 \%$ had drinking habits, being that $22.1 \%$ of the drivers drank alcoholic beverages two to four times per month.

The most common physical symptoms experienced in the past 24 hours were muscle tension (38\%), dry mouth $(26.2 \%)$, increased sweating $(25.5 \%)$, and change in appetite $(22.7 \%)$. Among the psychological symptoms, the sudden urge to start new projects stood out $(29.6 \%)$.

The most common physical symptoms experienced in the past week were constant tiredness $(41.4 \%)$ and feeling of constant physical strain (38\%). Increased blood pressure was reported by $10.3 \%$ of the drivers, resulting in a significant increase when compared to the percentage obtained in the past 24 hours. The most common psychological symptoms in the past week were irritability $(16.8 \%)$, constant thought about the same topic (14.3\%), and excessive emotional sensitivity (13.4\%).

The most common physical symptoms experienced by drivers in the past month were insomnia (17.4\%), excess gas (15.6\%), change in appetite $(11.5 \%)$, and frequent diarrhea (12.8\%). The most common psychological symptoms were constant and excessive tiredness $(30.8 \%)$, loss of sense of humor $(29.3 \%)$, desire to escape everything (25.2\%), daily distress, anxiety, or fear $(22.1 \%)$, and apathy, depression or prolonged anger (12.8\%).

A total of 86 participants had some level of stress: three drivers $(3.5 \%)$ were in the alarm stage, $65(75.6 \%)$ were in the resistance stage, two $(2.3 \%)$ were in the near-exhaustion stage, and 16 (18.6\%) were in the exhaustion stage. The numbers are even more concerning taking into account that $93.1 \%$ of the drivers reported the lack of activities to reduce stress in this population group and that $48 \%$ of the respondents reported job dissatisfaction.

Stress was associated with the working time in the company, rest time during working hours, sleep quality, and health self-assessment. Drivers who worked for more than 10 years in the company reported higher levels of stress $(47.1 \%)$ and the lack of rest during working hours (43.2\%). In relation to sleep quality, the numbers increased as the sleep quality decreased (regular - 34\%; bad $-48.4 \%$; terrible $-61.5 \%$ ). The same association was identified in health self-assessment, since the percentage of drivers increased as their health perception decreased: $8.9 \%$ of stressed bus drivers reported very good health and $50 \%$ a bad/ terrible health, as shown in Table 1. 
Table 1

Association between rest during working hours, sleep quality, working time, and health self-assessment in stressed and stress-free bus drivers

\begin{tabular}{|c|c|c|c|c|c|c|c|c|}
\hline \multirow[t]{2}{*}{ Variable } & \multicolumn{2}{|c|}{ Stressed } & \multicolumn{2}{|c|}{ Stress-free } & \multicolumn{2}{|c|}{ Total } & \multirow[t]{2}{*}{$O R$} & \multirow[t]{2}{*}{$95 \% \mathrm{CI}$} \\
\hline & $N$ & $\%$ & $N$ & $\%$ & $N$ & $\%$ & & \\
\hline \multicolumn{9}{|c|}{ Rest during working hours } \\
\hline Yes & 70 & 24.6 & 214 & 75.4 & 284 & 100.0 & $p^{(1)}=0.016$ & 1.00 \\
\hline No & 16 & 43.2 & 21 & 56.8 & 37 & 100.0 & & $2.33(1.15$ to 4.71$)$ \\
\hline Total Group & 86 & 26.8 & 235 & 73.2 & 321 & 100.0 & & \\
\hline \multicolumn{9}{|l|}{ Sleep quality } \\
\hline Excellent & 8 & 19.5 & 33 & 80.5 & 41 & 100.0 & $p^{(1)}<0.001$ & 1.00 \\
\hline Good & 19 & 14.6 & 111 & 85.4 & 130 & 100.0 & & $0.71(0.28$ to 1.76$)$ \\
\hline Regular & 36 & 34.0 & 70 & 66.0 & 106 & 100.0 & & $2.12(0.89$ to 5.07$)$ \\
\hline $\mathrm{Bad}$ & 15 & 48.4 & 16 & 51.6 & 31 & 100.0 & & $3.87(1.36$ to 11.00$)$ \\
\hline Terrible & 8 & 61.5 & 5 & 38.5 & 13 & 100.0 & & $6.60(1.70$ to 25.67$)$ \\
\hline Total Group & 86 & 26.8 & 235 & 73.2 & 321 & 100.0 & & \\
\hline
\end{tabular}

Working time

\begin{tabular}{|c|c|c|c|c|c|c|c|c|}
\hline Up to 1 year & 8 & 12.7 & 55 & 87.3 & 63 & 100.0 & $p^{(1)}=0.001$ & 1.00 \\
\hline Between 1 and 5 years & 34 & 27.2 & 91 & 72.8 & 125 & 100.0 & & $2.57(1.11$ to 5.95$)$ \\
\hline Between 5 and 10 years & 10 & 27.0 & 27 & 73.0 & 37 & 100.0 & & $2.55(0.90$ to 7.19$)$ \\
\hline Over 10 years & 24 & 47.1 & 27 & 52.9 & 51 & 100.0 & & $6.11(2.43$ to 15.38$)$ \\
\hline Total Group & 76 & 27.5 & 200 & 72.5 & 276 & 100.0 & & \\
\hline \multicolumn{9}{|l|}{ Health self-assessment } \\
\hline Very good & 5 & 8.9 & 51 & 91.1 & 56 & 100.0 & $\mathrm{p}^{(1)}<0.001$ & 1.00 \\
\hline Good & 33 & 20.9 & 125 & 79.1 & 158 & 100.0 & & 2.69 (1.00 to 7.29$)$ \\
\hline Regular & 41 & 44.1 & 52 & 55.9 & 93 & 100.0 & & 8.04 (2.94 to 21.98$)$ \\
\hline $\mathrm{Bad} /$ Terrible & 7 & 50.0 & 7 & 50.0 & 14 & 100.0 & & $10.20(2.53$ to 41.09$)$ \\
\hline Total Group & 86 & 26.8 & 235 & 73.2 & 321 & 100.0 & & \\
\hline
\end{tabular}

Note. ${ }^{*} p=5.0 \% . \mathrm{OR}=$ odds ratio. $\mathrm{CI}=$ Confidence interval. ${ }^{(1)}$ Pearson's Chi-square test.

Table 2 shows that stressed bus drivers in the alarm and resistance stages had been working from 1 to 5 years in the company, with a daily workload over 10 hours, did not rest during working hours, and perceived their sleep qual- ity as terrible and their health as regular. These data showed changes in the near-exhaustion and exhaustion stages, since bus drivers assessed their health as terrible and their sleep quality as bad. 
Table 2

Association between stress stages and the working time in the company, daily working hours, rest during work, sleep quality, and health self-assessment in stressed and stress-free bus drivers

\begin{tabular}{|c|c|c|c|c|c|c|c|c|c|}
\hline \multirow[t]{2}{*}{ Variable } & \multicolumn{2}{|c|}{ Stress-free } & \multicolumn{2}{|c|}{$\begin{array}{c}\text { Bus drivers in the } \\
\text { Alarm/Resistance } \\
\text { stage }\end{array}$} & \multicolumn{2}{|c|}{$\begin{array}{l}\text { Bus drivers in } \\
\text { Near-Exhaution } \\
\text { /Exhaustion } \\
\text { stage }\end{array}$} & \multicolumn{2}{|c|}{ TOTAL } & \multirow[t]{2}{*}{$O R$} \\
\hline & $N$ & $\%$ & $N$ & $\%$ & $N$ & $\%$ & $N$ & $\%$ & \\
\hline \multicolumn{10}{|l|}{ Working time } \\
\hline Up to 1 year & 55 & 87.3 & 6 & 9.5 & 2 & 3.2 & 63 & 100.0 & $p^{(2)}=0.003$ \\
\hline Between 1 and 5 years & 91 & 72.8 & 25 & 20.0 & 9 & 7.2 & 125 & 100.0 & \\
\hline Between 5 and 10 years & 27 & 73.0 & 9 & 24.3 & 1 & 2.7 & 37 & 100.0 & \\
\hline Over 10 years & 27 & 52.9 & 21 & 41.2 & 3 & 5.9 & 51 & 100.0 & \\
\hline Total Group & 200 & 72.5 & 61 & 22.1 & 15 & 5.4 & 276 & 100.0 & \\
\hline
\end{tabular}

Daily workload

\begin{tabular}{|c|c|c|c|c|c|c|c|c|c|}
\hline Up to $8 \mathrm{hrs}$ & 134 & 76.6 & 38 & 21.7 & 3 & 1.7 & 175 & 100.0 & $p^{(1)}=0.007$ \\
\hline Between $8 \mathrm{hrs}$ and $10 \mathrm{hrs}$ & 74 & 73.3 & 18 & 17.8 & 9 & 8.9 & 101 & 100.0 & \\
\hline Over $10 \mathrm{hrs}$ & 27 & 60.0 & 12 & 26.7 & 6 & 13.3 & 45 & 100.0 & \\
\hline Total Group & 235 & 73.2 & 68 & 21.2 & 18 & 5.6 & 321 & 100.0 & \\
\hline \multicolumn{10}{|l|}{ Rest during working hours } \\
\hline Yes & 214 & 75.4 & 56 & 19.7 & 14 & 4.9 & 284 & 100.0 & $p^{(1)}=0.048$ \\
\hline No & 21 & 56.8 & 12 & 32.4 & 4 & 10.8 & 37 & 100.0 & \\
\hline Total Group & 235 & 73.2 & 68 & 21.2 & 18 & 5.6 & 321 & 100.0 & \\
\hline \multicolumn{10}{|l|}{ Sleep quality } \\
\hline Very good & 33 & 80.5 & 7 & 17.1 & 1 & 2.4 & 41 & 100.0 & $p^{(3)}<0.001$ \\
\hline Good & 111 & 85.4 & 16 & 12.3 & 3 & 2.3 & 130 & 100.0 & \\
\hline Regular & 70 & 66.0 & 29 & 27.4 & 7 & 6.6 & 106 & 100.0 & \\
\hline Bad & 16 & 51.6 & 10 & 32.3 & 5 & 16.1 & 31 & 100.0 & \\
\hline Terrible & 5 & 38.5 & 6 & 46.2 & 2 & 15.4 & 13 & 100.0 & \\
\hline Total Group & 235 & 73.2 & 68 & 21.2 & 18 & 5.6 & 321 & 100.0 & \\
\hline \multicolumn{10}{|l|}{ Health self-assessment } \\
\hline Very good & 51 & 91.1 & 4 & 7.1 & 1 & 1.8 & 56 & 100.0 & $p^{(2)}<0.001$ \\
\hline Good & 125 & 79.1 & 27 & 17.1 & 6 & 3.8 & 158 & 100.0 & \\
\hline Regular & 52 & 55.9 & 33 & 35.5 & 8 & 8.6 & 93 & 100.0 & \\
\hline Bad/ Terrible & 7 & 50.0 & 4 & 28.6 & 3 & 21.4 & 14 & 100.0 & \\
\hline Total Group & 235 & 73.2 & 68 & 21.2 & 18 & 5.6 & 321 & 100.0 & \\
\hline
\end{tabular}

Note. ${ }^{*} p=5.0 \%$. OR = odds ratio. ${ }^{(1)}$ Pearson's Chi-square Test. ${ }^{(2)}$ Fisher's Exact Test. ${ }^{(3)}$ Likelihood-ratio test. 


\section{Discussion}

The sample of this study was mostly composed of married young men, which is in line with the studies conducted by Guterres et al. (2011) and Martins, Lopes, and Farina (2014) that emphasize the male predominance in this profession.

Bus drivers perceived alcohol consumption as a form of leisure and relaxation. This consumption usually happens on days off, that is, every 7 working days. Although bus drivers report alcohol consumption as being a distraction, more than $30 \%$ of the drivers have no time for leisure, which suggests the influence of this factor in the onset of stress.

The consequences of alcohol consumption in the workplace are associated with absenteeism, early retirement, accidents at work, as well as sick leaves (Bravo Ortiz \& Maziale, 2010).

Although only a small percentage of bus drivers had experienced sudden hypertension, attention should be paid to this situation since it is a syndromic and multifactorial disease.

In Curitiba-Paraná, a study conducted in an interstate company with 46 drivers found no association between stress and hypertension; the authors suggested that cortisol as a psychophysiological measure of stress should be assessed in order to avoid subjectivity (Silva, Keller, \& Coelho, 2013). Although this study does not confirm this association, Nóbrega, Castro, and Souza (2007) believe that there is a direct association between chronic mental stress and hypertension, which is more evident in men with a low socio-economic status and in jobs with little decision-making power.

The symptoms of work-related musculoskeletal disorders (WRMD) are closely related to neglected ergonomic aspects, which may be closely linked to the work environment (repetitive movements, position, and vehicle operation) and cognitive and/or profession-specific emotional stressors (Baltazar et al., 2008).

The presence of symptoms in the past week, such as constant tiredness and physical strain, suggests the need for longer breaks between trips with a view to reducing work overload. Pauses are directly influenced by traffic and possible accidents involving vehicles or pedestrians, thus reducing or precluding the period of rest. Drivers reported that they experienced excessive workload, enjoyed short breaks, and had exhausting work periods. In this way, bus drivers' stress level is associated with excessive workload, working time, and resting period between trips.

The terrible quality of sleep of these professionals can have a negative impact on all of those involved - passengers, pedestrians, other drivers, or even businesspeople in the transportation sector. This concern becomes evident given that physical-motor skills become significantly impaired due to lack of quality sleep, thus increasing the risk of traffic accidents.

Drivers who reported having a regular to terrible sleep quality and frequent insomnia episodes and nightmares had higher levels of stress.

Public bus drivers seemed tired of dealing with adverse situations every day, which interfered with their mental health. Symptoms such as emotional sensitivity, frequent irritability, constant thought about the same topic, constant and excessive tiredness, desire to escape everything, and loss of sense of humor demonstrate that these professionals' emotional health is damaged. In addition, almost half of the bus drivers reported job insatisfaction and reported the desire to start new projects.

In relation to symptoms, physical symptoms were more prevalent in the past 24 hours and in the past week than psychological symptoms, which were evident in the past month. This finding is not in line with the study conducted by Pinheiro and Lipp (2009), in which psychological symptoms predominated throughout the three time periods. This fact was justified by the high level of attention, constant stimuli, social interaction, and pressure for schedule fulfilment.

In a study conducted in Belo Horizonte with 124 bus drivers, Matos, Moraes, and Pereira (2015) found that $54.8 \%$ of them had stress $-94 \%$ were in the stage of resistance and $6 \%$ were in the stages of near-exhaustion $(4 \%)$ and alarm (2\%). A study conducted in the metropolitan region of a state capital in 
Southern Brazil, with 80 collective transport drivers, identified stress in $27.5 \%$ of the participants: $23.75 \%$ in the resistance stage and $3.75 \%$ in the exhaustion stage (Martins et al., 2014).

The resistance stage is characterized by the attempt to reach a state of balance and, by means of this reorganization, some initial symptoms begin to disappear; however, this stage uses the energy required for other vital functions, leading to eating disorders, excessive irritability, and even decreased libido. If it cannot recover, the body enters the exhaustion stage (Lipp \& Guevarra, 1994). In this case, both psychological and physical exhaustion may occur, leading to the onset of diseases (Lipp, 2000).

The prevalence of bus drivers in the resistance stage means that they are fighting and creating strategies to cope with stressors to which they are exposed in their work environment on a daily basis. However, the resistance stage is considered as borderline for the onset of stress-related physical and mental diseases. In this way, the nurse emerges as an important agent in the dissemination of health promotion, protection, and recovery strategies for both physical and psychological diseases with a view to ensuring the social well-being.

The exhaustion stage was the second most prevalent stage. At this stage, there is a complete imbalance of the organic systems, causing diseases such as hypertension, depression, anxiety, insomnia, diarrhea, and stroke. In this study, the worsening of symptoms is put into evidence by to the large percentage of stressed individuals in the exhaustion stage (Lipp, 2014).

Despite the existence of an institution responsible for these workers' occupational health, this study found that there were no activities to minimize the effects of stress. One of the limitations of this study was the initial difficulty in obtaining authorization for conducting the research from the companies involved in this study. In addition, drivers were unwilling to provide the necessary information for fear of suffering negative consequences at work.

Stress has affected bus drivers' health because those with higher stress levels rated their health as being terrible. In this way, the stress experienced by bus drivers seems to affect not only the physical and psychological conditions, but also the quality of the transportation system. The lack of initiatives to minimize stress requires the development of strategies aimed at implementing public policies targeted at these professionals. Thus, occupational stress is a public health issue that must be tackled in order to promote social well-being, given that bus drivers are key elements who promote and facilitate urban mobility.

\section{Conclusion}

Bus drivers reported different symptoms according to the chronological assessment of stress, with an increasing number of psychological symptoms in the time intervals under analysis. Stress is associated with working time, excessive daily workload, lack of time to rest, and poor sleep quality.

Taking into account bus drivers' social importance, inter-sector initiatives should be developed involving the transportation coordinators of these terminals and the secretariat of health with a view to implementing interventions to promote these professionals' mental health and provide a satisfactory work environment to help reduce stress levels and, consequently, promote their quality of life. More in-depth studies should be conducted on the major physical and psychological symptoms experienced by bus drivers, since these symptoms can be a starting point for the detection of syndromic psychological and occupational diseases.

However, nurses do not seem to be yet integrated into these professionals' healthrelated activities. In this context, nursing emerges as a profession that is committed to health promotion, protection, recovery, and rehabilitation in various health care settings.

\section{References}

Alquimim, A. F., Barral, A. B., Gomes, K. C., \& Rezende, M. C. (2012). Avaliação dos fatores de risco laborais e físicos para doenças cardiovasculares em motoristas de transporte urbano de ônibus em 
Montes Claros (MG). Ciência \& Saúde Coletiva, 17(8), 2151-2158.

Baltazar, C. C., Maia, E. R., Figueiredo, F. J., Correia, B. R., \& Holanda, S. A. (2008). Motorista de ônibus urbano e intermunicipal do triângulo de Crajubar: Uma abordagem ergonômica. Saúde \& Saúde Coletiva, 9(2). Retrieved from http://coletanea2008.no.comunidades.net/index. php?pagi$\mathrm{na}=1225359146$

Bravo Ortiz, C. M., \& Marziale M. H. (2010). El consumo de alcohol en personal administrativo y de servicios de una universidad del Ecuador. Revista Latino-Americana de Enfermagem, 18( ${ }^{\circ}$ esp.), 487495.

Goulart Junior, E., \& Lipp, M. E. (2008). Estresse entre professoras do ensino fundamental de Escolas Públicas Estaduais. Psicologia em Estudo, 13(4), $847-$ 857.

Guterres, A., Duarte D., Siqueira, F. V., \& Silva, M. C. (2011). Prevalência e fatores associados a dor nas costas dos motoristas e cobradores do transporte coletivo da cidade de Pelotas-RS. Revista Brasileira de Atividade Física \& Saúde, 16(3), 240-245.

Lipp, M. E., \& Guevara, A. J. (1994). Validação empírica do inventário de sintomas de stress. Estudos de Psicologia, 1(3), 43-49.

Lipp, M. E. (2000) Inventário de Sintomas de Stress para Adultos de Lipp (ISSL). São Paulo, Brasil: Casa do Psicólogo.
Lipp, M. E. (Org.). (2004) O stress no Brasil: Pesquisas avançadas. São Paulo, Brasil: Papirus.

Lipp, M. E. (2014). Manual do Inventário dos Sintomas de Stress para Adultos de Lipp. São Paulo, Brasil: Casa do Psicólogo.

Martins, F. F., Lopes, R. M., \& Farina, M. (2014). Nível de estresse e principais estressores do motorista de transporte coletivo. Boletim: Academia Paulista de Psicologia, 34(87), 523-536.

Matos, M. G., Moraes, L. F., \& Pereira, L. Z. (2015). Análise do estresse ocupacional em motoristas de coletivo urbano na cidade de Belo Horizonte. Revista Gestão \& Tecnologia, 15(1), 256-275.

Nóbrega, A. C., Castro, R. R., \& Souza, A. C. (2007). Estresse mental e hipertensão arterial sistêmica. Revista Brasileira de Hipertensão, 14(2), 94-97.

Pinheiro, C. R., \& Lipp, M. E. (2009). Stress ocupacional e qualidade de vida em clérigos(as). Boletim: Academia Paulista de Psicologia, 29(1), 126-141.

Prange, A. P. (2011). "Quem dá mais, cobra mais!": uma análise das normas antecedentes do ofício dos motoristas de ônibus em um contexto específico. Estudos e Pesquisa em Psicologia, 11(2), 551-565.

Selye, H. (1959). Stress: A tensão da vida. São Paulo, Brasil: Ibrasa.

Silva, A. M., Keller, B., \& Coelho, B. W. (2013). Associação entre pressão arterial e estresse percebido em motoristas de ônibus. Journal of The Health Sciences Institute, 31(1), 75-78. 
